\title{
Transport of Particulate Organic Carbon Through the North Inlet Ecosystem*
}

\author{
Thomas H. Chrzanowski ${ }^{1 * *}$, L. Harold Stevenson ${ }^{1 * * *}$ and John D. Spurrier ${ }^{2}$
}

Belle W. Baruch Institute for Marine Science and Coastal Research, and Departments of Biology (1) and Mathematics and Statistics (2), University of South Carolina, Columbia, South Carolina 29208, USA

\begin{abstract}
Tidal fluctuations and transports of particulate organic carbon (POC) were investigated at 3 marsh creeks (near Georgetown, South Carolina, USA) comprising the major transfer points between the North Inlet Marsh and the adjoining aquatic ecosystems. Two creeks, Town and North Jones, form the inlet mouth and are the only marsh-ocean exchange points. The third creek, South Jones, connects to a brackish water embayment. The creeks were simultaneously sampled every $1.5 \mathrm{~h}$ for 50 consecutive hours during neap tides (4 tidal cycles) and 50 consecutive hours during corresponding spring tides of each season. At the inlet, POC concentrations fluctuated in-phase with the tide during the winter and out-of-phase with the tide during the summer Combinations of in-phase and out-of-phase patterns occurred in spring and fall. The fluctuations at the brackish water location were irregular POC concentrations were similar in each season with values averaging about $1.4 \mathrm{~g} \mathrm{~m}^{-3}$. Net transports varied from tidal cycle to tidal cycle with regard to direction of transport (import or export) and magnitude, ranging from a net import of $240 \mathrm{gPOC} \mathrm{s}^{-1}$ to a net export of $228 \mathrm{~g} \mathrm{POC} \mathrm{s}^{-1}$. Annual budgets revealed Town Creek to export POC at a rate of $2.6 \pm 0.5 \times 10^{9} \mathrm{~g} \mathrm{yr}^{-1}$; North Jones Creek imported POC at a rate of $3.8 \pm 0.7 \times 10^{8} \mathrm{~g} \mathrm{yr}^{-1}$; and South Jones Creek exported POC at a rate of $5.5 \pm 0.8 \times 10^{8} \mathrm{~g} \mathrm{yr}^{-1}$ The 3222 ha North Inlet marsh serves as a source of POC to the ocean at a rate of $87 \pm 16 \mathrm{~g}$ of POC per $\mathrm{m}^{2} \mathrm{yr}^{-1}$.
\end{abstract}

\section{INTRODUCTION}

Spartina dominated salt marshes of the southeastern United States are highly productive ecosystems. Net primary production ranges from 650 to $1000 \mathrm{~g}$ dry biomass $\mathrm{m}^{-2} \mathrm{yr}^{-1}$ in North Carolina (Williams and Murdock, 1966, 1969; Stroud and Cooper, 1968) to 1300 to $3700 \mathrm{~g}$ dry biomass $\mathrm{m}^{-2} \mathrm{yr}^{-1}$ in Georgia (Gallagher et al., 1980). This production was the impetus behind the concept that salt marshes serve as sources of organic material that can be exported from a marsh to the near-shore oceanic environment via tidal flushing (Teal, 1962; Odum and de la Cruz, 1967). Presumably, organic matter may be transported out of the marsh in a variety of forms, as Spartina wrack, detritus, or planktonic microbiota. The concept of organic matter trans-

\footnotetext{
- Contribution No. 429 of the Belle W. Baruch Library in Marine Science

- Present address: Department of Biology, University of Texas-Arlington, Arlington, Texas 76019, USA

-.. Present address: Department of Environmentäl Sciences and Microbiology, McNeese State University, Lake Charles, Louisiana 70609, USA
}

port via tidal exchange has been a central part of ecological thought for approximately $20 \mathrm{yr}$ and several attempts have been made to gather data that would empirically test the concept. Nixon (1980) has identified 8 marsh systems for which annual particulate carbon budgets have been generated. The marshes studied include: Gott's Marsh, MD (Heinle and Flemer, 1976), Flax Pond, NY (Woodwell et al., 1977), Great Sippewissett Marsh, MA (Valiela et al., 1978), 2 York River marshes, Carter and Ware Creeks (Axelrad et al., 1976), Dill Creek Marsh, SC (Settlemeyer and Gardner, 1975, 1977), and Baritaria Bay, LA (Happ et al., 1977). Considering the studies where data are available for well-defined salt marshes, net outwelling of particulate organic carbon (POC) is suggested. Nixon (1980) cautioned that few of these data have been subjected to statistical analyses and many of the studies have not paid enough attention to water discharge. Regarding the Atlantic coast marshes for which annual carbon budgets have been generated, each of the marshes, with the exception of the small Dill Creek system (SC), are located along the northern portions of the coast. There is a lack of information for 
large undisturbed marshes of the southeastern portion of the coast.

The absence of a data base on transports of materials through southeastern marshes, weak statistical analyses of transport information for northeastern marshes, and continuing destruction through increasing development of marshes clearly point to the need for an evaluation of material exchanges between a southeastern marsh and the coastal ocean. The results presented here add to our knowledge of carbon transports through southeastern salt marshes by reporting on tidally induced fluctuations in concentrations and net transports of POC between a large undisturbed salt marsh and the bordering aquatic environments. The experimental design allowed a statistical evaluation of the net measured movement of POC relative to zero transport and also permitted an estimation of an annual POC transport budget.

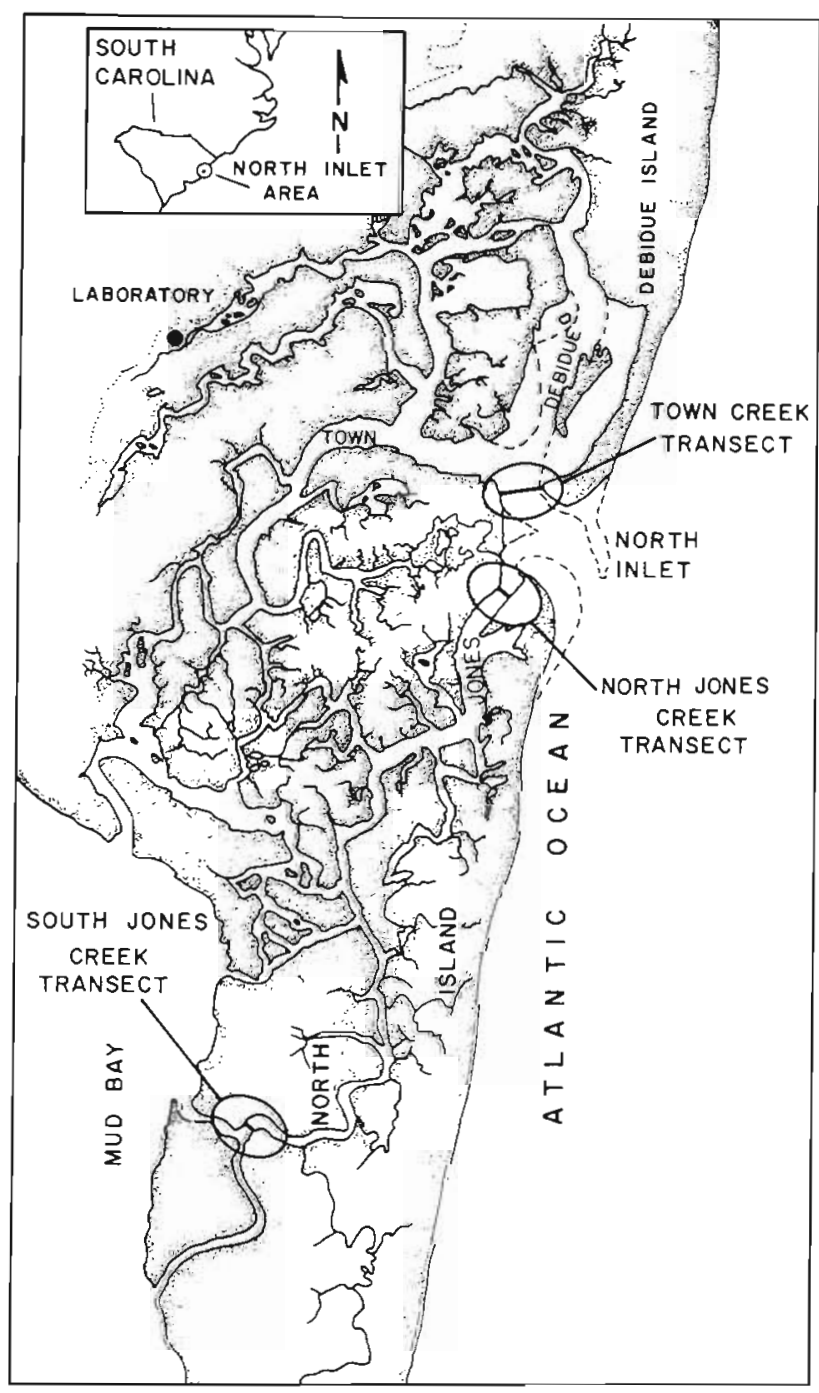

Fig. 1. Location of marsh and transects where the flux of particulate organic carbon was monitored

\section{METHODS}

\section{Environmental Setting}

The North Inlet Marsh (Fig. 1) is approximately 3200 ha and located near Georgetown, South Carolina $\left(33^{\circ} 20^{\prime} \mathrm{N}, 79^{\circ} 10^{\prime} \mathrm{W}\right)$. The marsh system has a single inlet to the sea, North Inlet, and 3 major tidal creeks, Debidue, Town and Jones. The marsh creeks have a mean tide range of $1.7 \mathrm{~m}$ and are typically only $3 \mathrm{~m}$ deep at mean tide level. Peak current velocities have been recorded at $2.3 \mathrm{~m} \mathrm{~s}^{-1}$ in Town Creek. The northern portion of the marsh is influenced by oceanic waters and the salinity seldom falls below $32 \%$. The marsh is bordered to the south by Mud Bay, a brackish water embayment and salinities are lower and more variable. The dominant flora is the cordgrass Spartina: within the northern high-salinity areas, S. alterniflora, and within the low-salinity southern areas, $S . c y$ nosuroides. Freshwater input into the northern section is primarily in the form of runoff, and typically less than $1 \%$ of the tidal prism ( $T$. Williams, Clemson University, unpubl.).

\section{Sampling Procedures}

Samples were collected seasonally throughout 1979 from 2 transects near North Inlet and from a 3rd transect near Mud Bay (Fig. 1). The Town Creek transect was sampled from 3 boats and both Jones Creek transects (hereafter North Jones Creek and South Jones Creek) were sampled from 2 boats each. Boats were positioned so data would accurately reflect material flows through the transects (for a detailed discussion of station placement, see Chrzanowski et al., 1979 and Kjerfve et al., 1981).

At Town and North Jones Creeks water was pumped (Guzzler Pump, Dart Union Corp.) from 3 depths, $0.2 \mathrm{~m}$ below surface, $0.2 \mathrm{~m}$ above bottom, and a midway point. At South Jones Creek water was pumped from $0.2 \mathrm{~m}$ below the surface and $0.2 \mathrm{~m}$ above the bottom. Water was collected in sterile, acid-washed, 500-ml glass bottles and immediately transported to laboratory facilities onshore. Samples were collected every 1.5 lunar h $(93 \mathrm{~min})$ for approximately $50 \mathrm{~h}$ during neap tides and spring tides (with the exception of the winter when samples were collected during mid tides).

\section{Analytical Procedures}

POC was measured using the method of Strickland and Parsons (1968). POC contained in $50 \mathrm{ml}$ sub-samples (not prescreened) was collected on precombusted 
47-mm glass-fiber filters (Whatman, GF/F) usually within 2 h of sample collection. The filters were held over concentrated $\mathrm{HCl}$ for several seconds, placed in precombusted 10-ml glass ampules (Oceanography International), dried $\left(100^{\circ} \mathrm{C}, 3 \mathrm{~d}\right)$, purged with oxygen, sealed, and combusted for $4 \mathrm{~h}$ at $480^{\circ} \mathrm{C}$. The resulting $\mathrm{CO}_{2}$ was analysed with an infrared analyser (Beckman model 215A).

Velocity measurements were taken with water samples using biplane current crosses (Pritchard and Burt, 1951). These data were computer-fitted to a smooth curve and new values extrapolated at every one-tenth depth from surface to bottom. For detailed descriptions of this procedure, methods for cross-sectional bathymetry, and tide curve construction, consult Kjerfve (1975) and Chrzanowski et al. (1979).

The instantaneous transport was calculated from:

$$
F=\varrho \sum_{j=1}^{N} \frac{h_{\mathrm{j}}}{10}\left(0.5 V_{o j} W_{o j} C_{o j}+\sum_{j=1}^{N} V_{1 j} W_{i j} C_{1 j}\right)
$$

where $F=$ transport; $\varrho=$ water density $\left(1.02 \mathrm{~g} \mathrm{ml}^{-1}\right)$; $N=$ number of sampling stations; $h_{j}=$ depth at the $j^{\text {th }}$ station; $V_{o j}, W_{o j}$, and $C_{o j}=$ velocity, width, and concentration at the surface of the $j^{\text {th }}$ station; $V_{i j}, W_{i j}$, and $C_{i j}=$ velocity, width, and concentration at the $i^{\text {th }}$ depth of the $j^{\text {th }}$ station (Kjerfve et al., 1981). Single tidal cycle transports were calculated by summing the instantaneous mass transport values for each tidal cycle.

Sustained rhythms were detected, mathematically defined, and incorporated in a descriptive equation to calculate average net transport for each 4 tidal cycles. The equation fits instantaneous POC transport ( $F$, Eq. 1) as a function of time ( $T$, hours from an arbitary starting point) and calculates a mean instantaneous transport $\left(\mu, \mathrm{g} \mathrm{s}^{-1}\right)$ for each 4 consecutive tidal cycles. The descriptive equation is

$$
\begin{aligned}
F=\mu & +\alpha_{1} \operatorname{Sin}(2 \pi T / 24.84)+\beta_{1} \operatorname{Cos}(2 \pi T / 24.84) \\
& +\alpha_{2} \operatorname{Sin}(2 \pi T / 12.42)+\beta_{2} \operatorname{Cos}(2 \pi T / 12.42) \\
& +\alpha_{3} \operatorname{Sin}(2 \pi T / 6.21)+\beta_{3} \operatorname{Cos}(2 \pi T / 6.21)+\varepsilon
\end{aligned}
$$

where $\mu=$ mean instantaneous net transport; $\alpha_{1}, \alpha_{2}, \alpha_{3}$, $\beta_{1}, \beta_{2}, \quad \beta_{3}=$ coefficients; $\varepsilon=$ a random error term. Instantaneous transports are a result of the tidal periods $(24.84,12.42$, and $6.21 \mathrm{~h})$ were included to explain deviations from the mean net transport $(\mu)$. Sine and cosine terms are incorporated to explain variability resulting from tidal oscillations and reduce the standard error of the estimator of $\mu$, allowing for a statistical test of significance.

The equation is a form of general linear model and least squares estimates of $\mu$ and coefficients were found using the general linear model procedures of the SAS computing package (Helwig and Council, 1979).

\section{RESULTS}

Two distinct fluctuation patterns were observed in POC concentrations at the ocean interfaces. One pattern, typical of data collected during the winter, is described by maximum levels of POC bimodally distributed around high tide and minimal concentrations at low tide (Fig. 2). The second pattern, typical of summer data, is described by minimal POC concentrations at high tide and maximum concentrations at low tide (Fig. 9). On occasions, mixtures of the 2 patterns were observed. The temporal fluctuations at the brackish water location were predominantly erratic.
Fig. 2. Temporal fluctuations in concentration of particulate organic carbon (POC), relative tidal height, and instantaneous net flux of POC at Town Creek in February. In this and following figures POC concentrations (broken line) and tide level (smooth line) are illustrated in upper panels and net flux values in lower panels. In lower panels, positive flux values indicate export from the marsh; negative flux values signify import

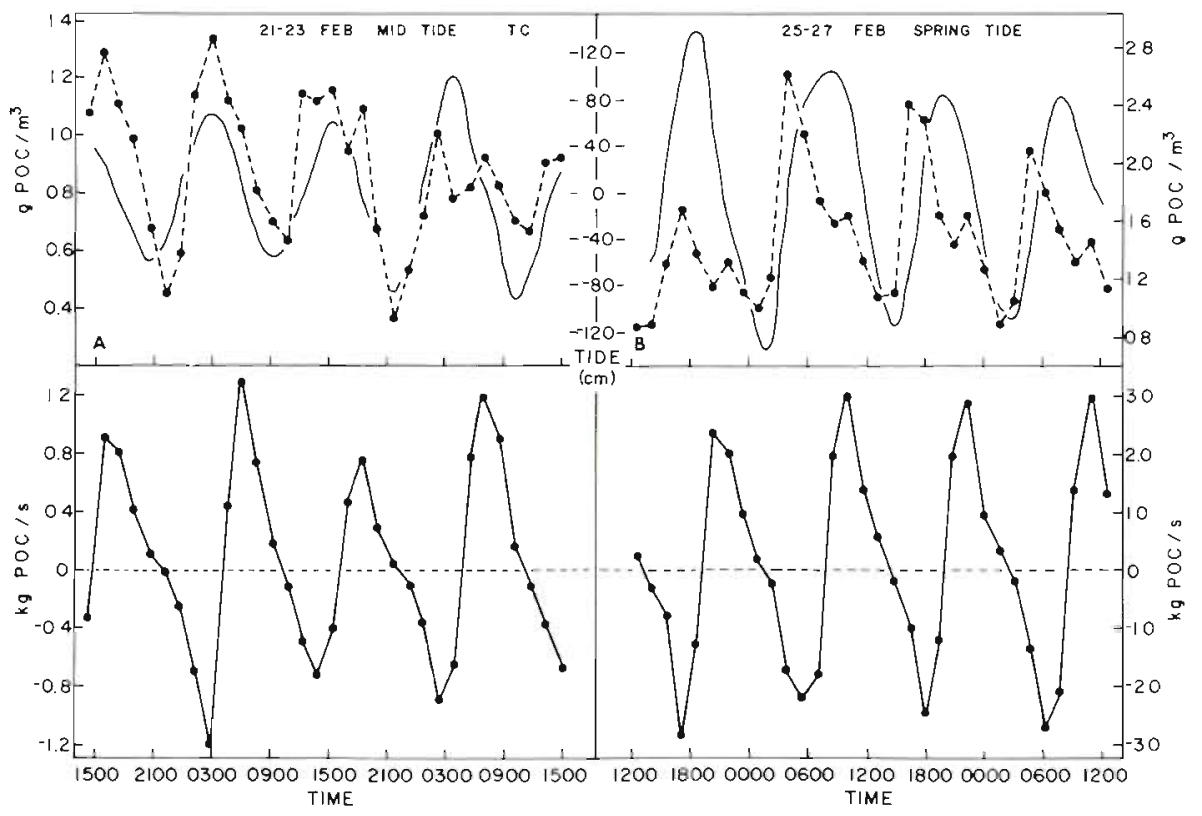




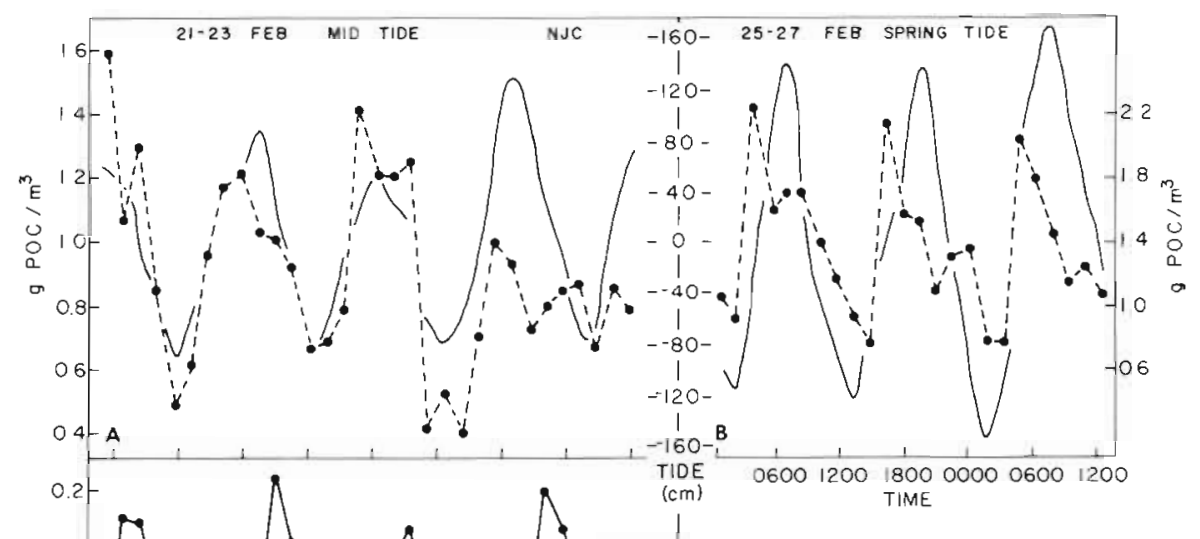

Fig. 3. Temporal fluctuations in concentration of particulate organic carbon (POC), relative tidal height, and instantaneous net flux of POC at North Jones Creek in February. Instantaneous flux values for the spring tide (B) are not $150021000300090015002100030009001500 \quad$ available

Regardless of the type of temporal concentration patterns, the transport patterns were typically rhythmic, with peak transports corresponding to maxima in water discharge (Fig. 2). Exceptions were noted at South Jones Creek. The standard error of the mean POC concentration at each sampling interval was less than $10 \%$ of the mean for more than $90 \%$ of sampling intervals. Consequently, error bars were omitted from the figures. The relative tidal height, concentrations of POC, directional transport, and descriptive statistics are presented below for each sampling period and organized by creek on a seasonal basis.

\section{Winter}

The temporal fluctuations of POC concentration were similar at Town and North Jones Creeks during the mid-and spring-tide sampling periods (Figs. 2 and 3). POC concentrations were in phase with the tidal fluctuations; maximum levels during periods of high tide and minimum concentrations during low tide. Peak concentrations were bimodally distributed around high tide with elevated levels immediately before and after highest water level. Higher concentrations of POC were commonly found during rising water and corresponded to maximum flood-directed discharge of POC (Fig. 2B). Secondary concentration peaks occurred immediately after high tide and were usually coincident with maximum ebb-directed discharge of POC. Maximum concentrations on falling tides were 24 to $41 \%$ lower than the maximum levels on rising tides. At South Jones Creek, the temporal POC fluctuations and transport data were erratic (Fig. 4). The rhythmic pattern describing POC levels and the correlation of peak concentration to maximum

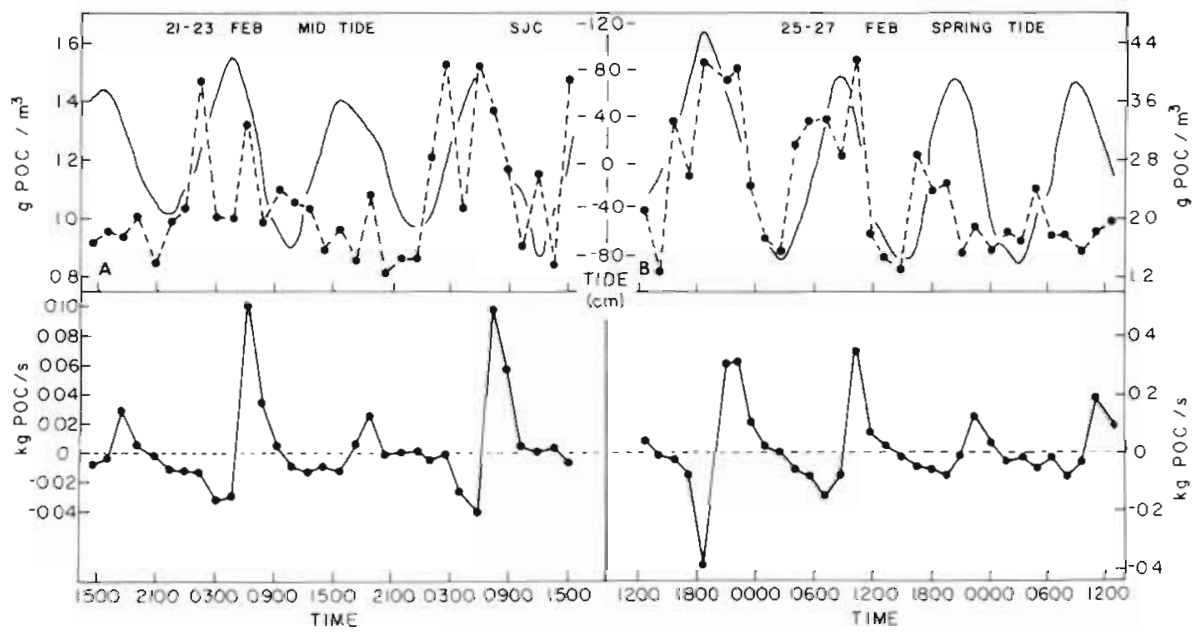

Fig. 4. Temporal fluctuations in concentration of particulate organic carbon (POC), relative tidal height, and instantaneous net flux of POC at South Jones Creek in February 
Table 1 Descriptive statistics for POC collected during each tidal series at each transect

\begin{tabular}{|c|c|c|c|c|c|c|c|c|}
\hline \multirow[b]{2}{*}{ Date } & \multirow[b]{2}{*}{$\begin{array}{l}\text { Tidal } \\
\text { series }\end{array}$} & \multirow[b]{2}{*}{ Transect ${ }^{*}$} & \multirow[b]{2}{*}{$N$} & \multicolumn{5}{|c|}{$\mathrm{g} P O C \mathrm{~m}^{-3}$} \\
\hline & & & & Mean & $\begin{array}{c}\text { Minimum } \\
\text { value }\end{array}$ & $\begin{array}{l}\text { Maximum } \\
\text { value }\end{array}$ & Range & $\begin{array}{l}\text { Seasonal } \\
\text { mean }\end{array}$ \\
\hline \multirow{3}{*}{ Feb 21-23 } & \multirow{3}{*}{ Mid } & $\mathrm{TC}$ & 1056 & 0.9 & 0.2 & 2.2 & 2.0 & \multirow{6}{*}{1.3} \\
\hline & & NJ & 704 & 0.9 & 0.2 & 2.4 & 2.2 & \\
\hline & & SJ & 704 & 1.1 & 0.5 & 2.5 & 2.0 & \\
\hline \multirow{3}{*}{ Feb 25-27 } & \multirow{3}{*}{ Spr } & TC & 1056 & 1.5 & 0.7 & 3.4 & 2.7 & \\
\hline & & $\mathrm{NJ}$ & $264^{\cdots}$ & 1.4 & 0.7 & 2.5 & 1.8 & \\
\hline & & SJ & 704 & 2.4 & 0.7 & 5.6 & 4.9 & \\
\hline \multirow{3}{*}{ May $18-20$} & \multirow{3}{*}{ Neap } & $\mathrm{TC}$ & 1056 & 1.5 & 0.6 & 3.0 & 2.4 & \multirow{6}{*}{1.5} \\
\hline & & NJ & 704 & 1.1 & 0.5 & 2.0 & 1.5 & \\
\hline & & SJ & 704 & 1.7 & 0.9 & 4.4 & 3.5 & \\
\hline \multirow{3}{*}{ May $25-27$} & \multirow{3}{*}{ Spr } & $\mathrm{TC}$ & 1056 & 1.5 & 0.5 & 2.8 & 2.3 & \\
\hline & & $\mathrm{NJ}$ & 704 & 1.2 & 0.6 & 2.9 & 2.3 & \\
\hline & & $\mathrm{SJ}$ & 704 & 1.9 & 0.8 & 4.4 & 3.6 & \\
\hline \multirow{3}{*}{ July 17-19 } & \multirow{3}{*}{ Neap } & $\mathrm{TC}$ & 1056 & 1.1 & 0.5 & 2.9 & 2.4 & \multirow{6}{*}{1.3} \\
\hline & & $\mathrm{NJ}$ & 704 & 1.1 & 0.4 & 3.8 & 3.4 & \\
\hline & & SJ & 704 & 1.8 & 0.7 & 4.8 & 4.1 & \\
\hline \multirow{3}{*}{ July $10-12$} & \multirow{3}{*}{ Spr } & $\mathrm{TC}$ & 1056 & 1.1 & 0.1 & 2.0 & 1.9 & \\
\hline & & NJ & $352 \cdots$ & 1.0 & 0.5 & 1.7 & 1.2 & \\
\hline & & SJ & 704 & 1.8 & 0.9 & 3.8 & 2.9 & \\
\hline \multirow{3}{*}{ Oct $26-28$} & \multirow{3}{*}{ Neap } & $\mathrm{TC}$ & 1056 & 1.0 & 0.3 & 2.3 & 2.0 & \multirow{6}{*}{1.5} \\
\hline & & NJ & 704 & 0.9 & 0.3 & 3.6 & 3.3 & \\
\hline & & SJ & 704 & 1.4 & 0.6 & 7.8 & 6.2 & \\
\hline \multirow{3}{*}{ Nov $2-4$} & \multirow{3}{*}{ Spr } & TC & 1056 & 1.7 & 0.6 & 2.9 & 2.3 & \\
\hline & & $\mathrm{NJ}$ & 704 & 1.6 & 0.1 & 3.1 & 3.0 & \\
\hline & & $\mathrm{SJ}$ & 704 & 2.7 & 1.0 & 8.8 & 7.8 & \\
\hline \multicolumn{9}{|c|}{$\begin{array}{l}\text { - TC Town Creek Transect; NJ North Jones Creek Transect; SJ South Jones Creek Transect } \\
\text { - Based on Station } 1 \text { only, } 3 \text { tidal cycles } \\
\text { - Based on Station } 1 \text { only }\end{array}$} \\
\hline
\end{tabular}

Fig. 5. Temporal fluctuations in concentration of particulate organic carbon (POC), relative tidal height, and instantaneous net flux of POC at Town Creek in May

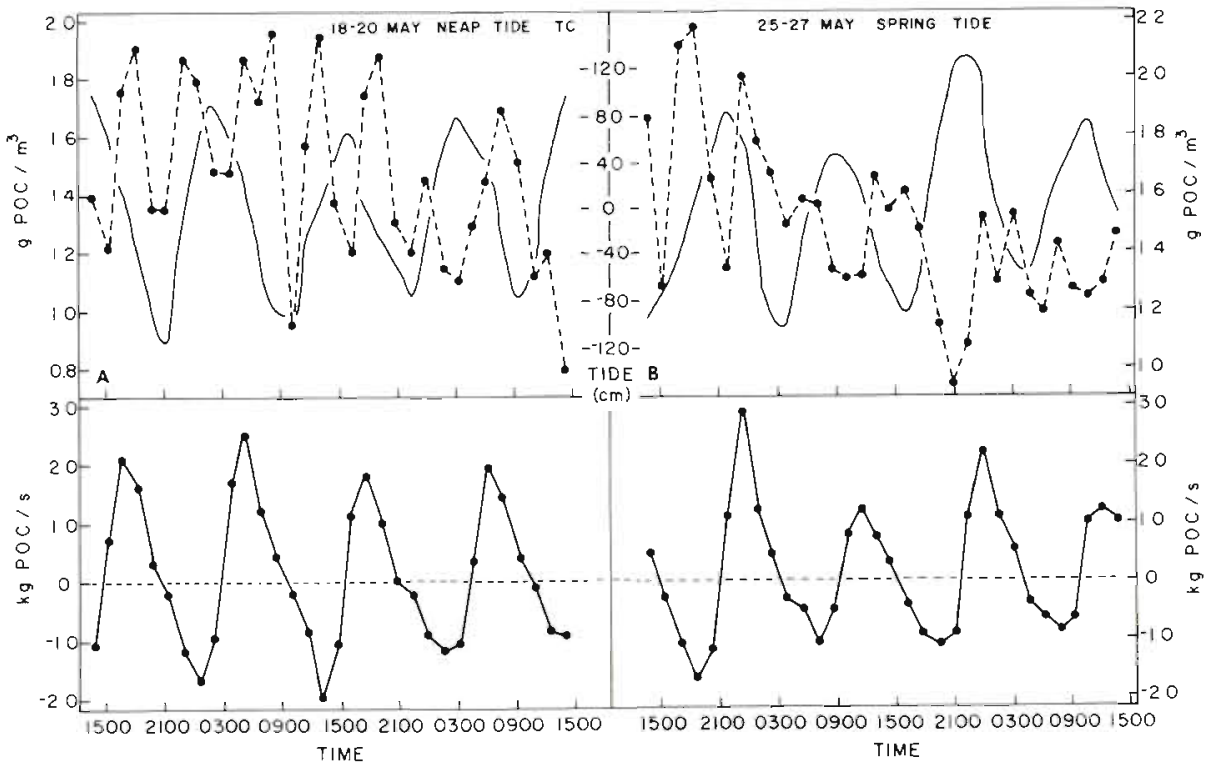



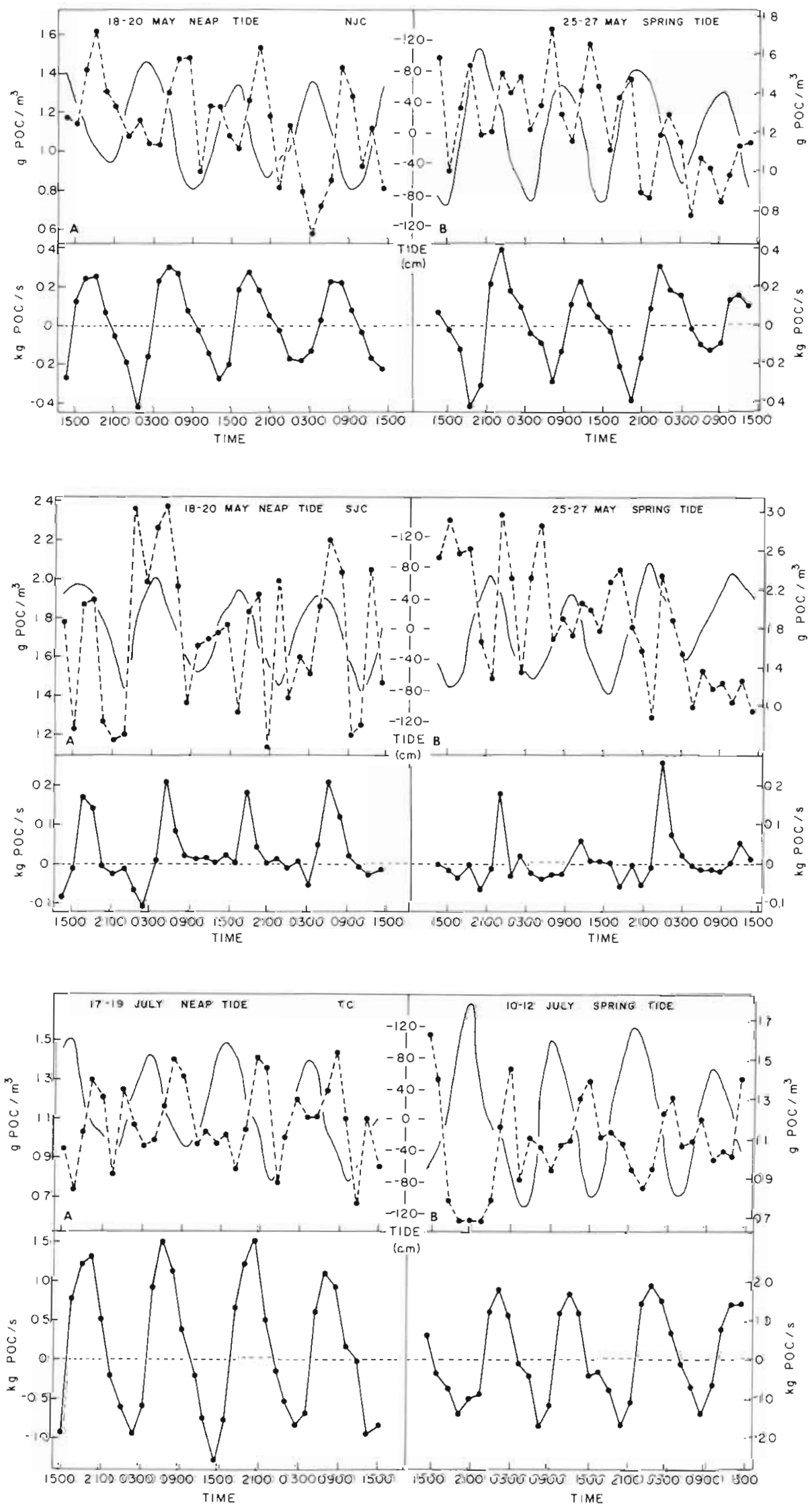

Fig. 6. Temporal fluctuations in concentration of particulate organic carbon (POC), relative tidal height, and instantaneous net flux of POC at North Jones Creek in May

Fig. 7. Temporal fluctuations in concentration of particulate organic carbon (POC), relative tidal height, and instantaneous net flux of POC at South Jones Creek in May

Fig. 8. Temporal fluctuations in concentration of particulate organic carbon (POC), relative tidal height, and instantaneous net flux of POC at Town Creek in July 
Fig. 9. Temporal fluctuations in concentration of particulate organic carbon (POC), relative tidal height, and instantaneous net flux of POC at North Jones Creek in July. Instantaneous flux values for the spring tide (B) are not available

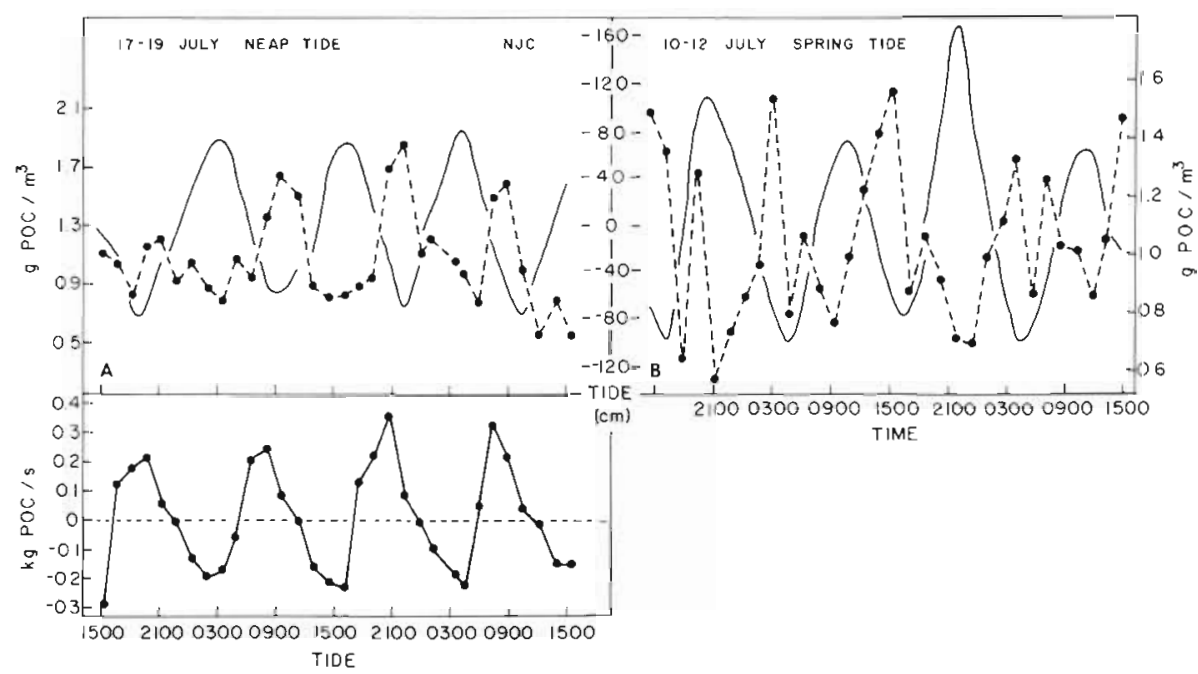

flux at the northern locations occurred only once at South Jones Creek, during the second high tide of the spring tide sampling (Fig. 4B).

Average $\mathrm{POC}$ levels at the northern locations were similar during mid and spring tide samplings (Table 1). Average POC concentrations at South Jones Creek were higher than concentrations observed at the northern transects. The maximum winter concentration, $5.6 \mathrm{~g} \mathrm{POC} \mathrm{m}^{-3}$, occurred during the spring tide at South Jones Creek.

\section{Spring}

The in-phase tidal rhythm and bimodal distribution of POC concentrations during the winter at Town and North Jones Creeks occurred frequently during the spring (Figs. 5 and 6). Additionally, high levels frequently occurred at low tide. The North Jones Creek, neap tide data are illustrative as elevated levels occurred just prior to low tide on 3 of 4 tidal cycles (Fig. 6A). POC fluctuations at South Jones Creek were not as erratic as during the winter (Fig. 7). Maximum POC concentrations were often around high tide and frequently corresponded to maximum POC discharge.

The maximum POC concentration during the May neap-tide at Town Creek, $3.0 \mathrm{~g} \mathrm{~m}^{-3}$, was only slightly greater than the maximum for the spring tide sampling at the same location (Table 1). Mean concentrations at North Jones Creek were 1.1 and $1.2 \mathrm{~g} \mathrm{POC} \mathrm{m}^{-3}$ for the neap and spring tides respectively.

\section{Summer}

At Town and North Jones Creeks the POC concentrations fluctuated out-of-phase with the tide (Figs. 8 and 9). Maximum POC levels were at low tide and minimum levels were around high tide - reverse of the winter pattern. The highest concentrations at Town Creek were just prior to slack low water and only rarely did peak concentrations correlate with transport maxima. During neap tides at North Jones Creek, concentration maxima occurred at slack low tide during 3 of the tidal cycles (Fig. 9A); whereas, during spring tides, levels resembled those obtained at Town Creek with maximum concentrations just prior to low tide (Fig. 9B). At South Jones Creek, POC concentrations resembled the patterns at the northern locations during May (Fig. 10). A mixture of patterns were apparent with concentrations frequently corresponding to transport maxima and elevated concentrations occasionally at low tide.

The mean POC concentrations at Town and North Jones Creeks were essentially the same (approximately $1.1 \mathrm{~g} \mathrm{POC}^{-3}$ ) during both neap and spring tides (Table 1). The mean concentrations at South Jones Creek were also similar for neap and spring tides $\left(1.8 \mathrm{~g} \mathrm{~m}^{-3}\right)$, slightly higher than the means at the northern locations.

Fall

Fluctuations of POC concentrations at Town and North Jones Creeks were similar to the patterns in the May data, with mixtures of in-phase and out-of-phase oscillations (Figs, 11 and 12). Data from neap tides (Figs. 11A and 12A) exhibited this mixture to a greater extent than the data for spring tides (Figs. 11B and 12B). POC fluctuation patterns during spring tides were similar to those of the summer samplings, with elevated levels more closely corresponding to low tide periods than high tide periods or peak transports. High concentrations associated with peaks in transport occurred frequently throughout the eight tidal cycles monitored at South Jones Creek (Fig. 13). Despite this association, there was an absence of the rhythmic 

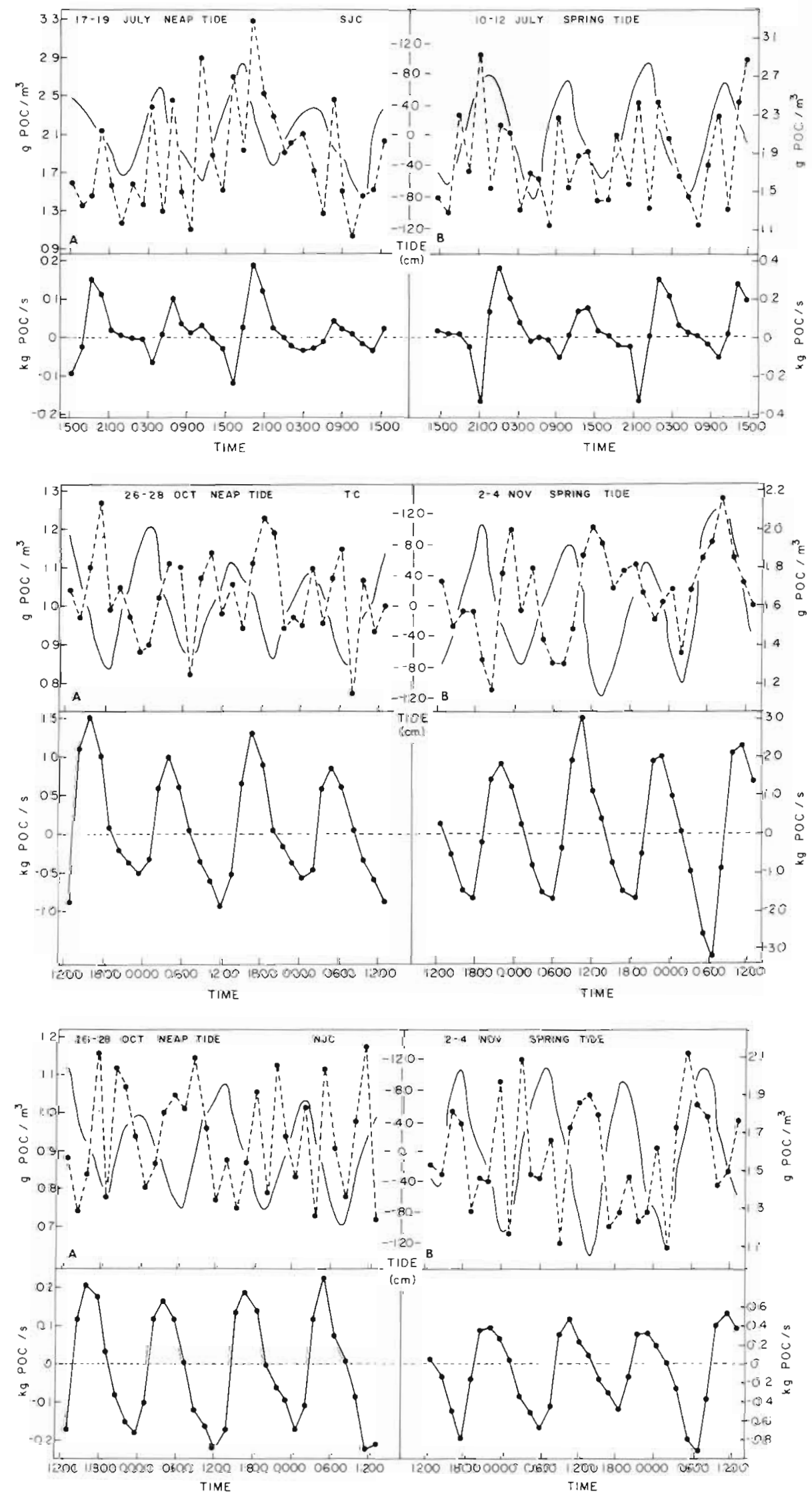

Fig. 10. Temporal fluctuations in concentration of particulate organic carbon (POC), relative tidal height, and instantaneous net flux of POC at South Jones Creek in July

Fig. 11. Temporal fluctuations in concentration of particulate organic carbon (POC), relative tidal height, and instantaneous net flux of POC at Town Creek in October and November

Fig. 12. Temporal fluctuations in concentration of particulate organic carbon (POC), relative tidal height, and instantaneous net flux of POC at North Jones Creek in October and November 
Fig. 13. Temporal fluctuations in concentration of particulate organic carbon (POC), relative tidal height, and instantaneous net flux of POC at South Jones Creek in October and November

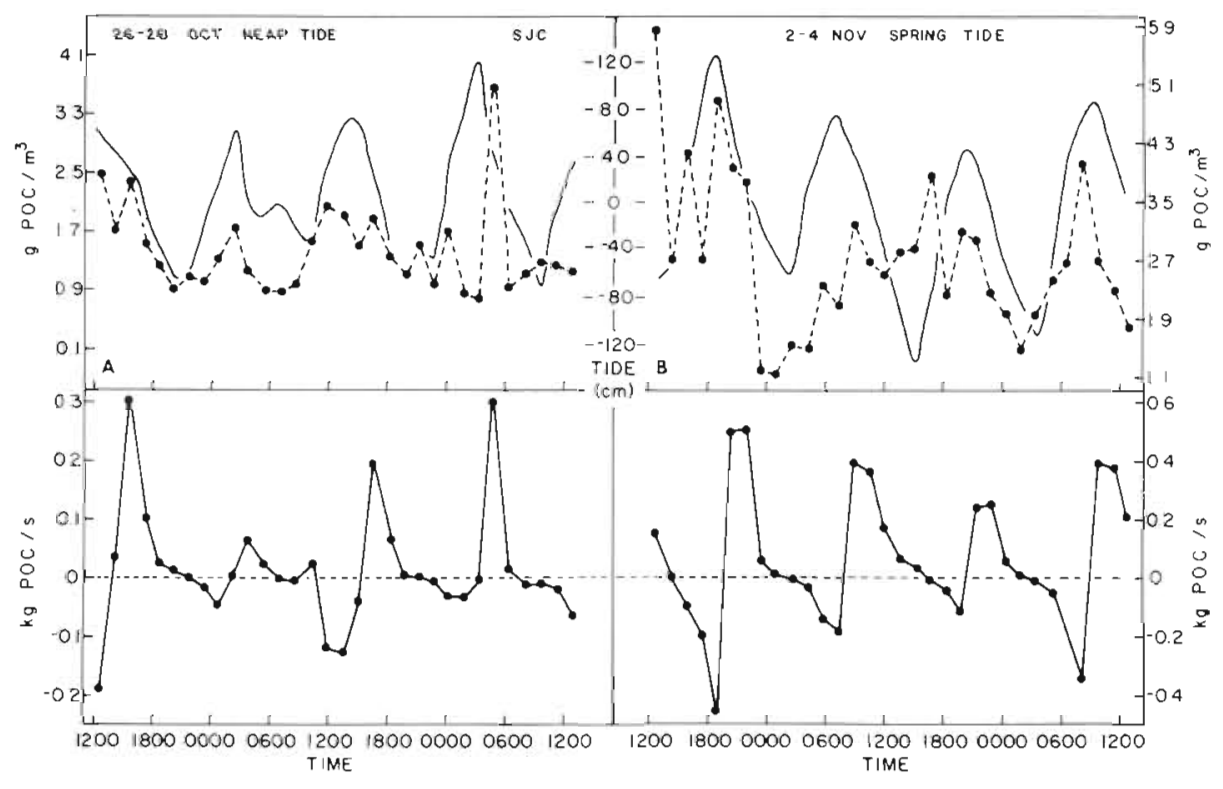

varied dramatically. The greatest import at Town Creek for a single tidal cycle was $240 \mathrm{~g} \mathrm{POC} \mathrm{s}^{-1}$, representing approximately $11 \mathrm{~kg}$ POC per tidal cycle (Cycle 4, spring tide, November). The highest export rate at Town Creek, $228 \mathrm{~g}$ POC s${ }^{-1}$, (Cycle 2, spring tide, November) was nearly as large as the maximum import rate. POC was exported from Town Creek on 30 of the 32 tidal cycles $(94 \%)$ and resulted in a net outwelling of POC during each tidal series (Table 3).

At North Jones Creek, the maximum import rate was about half the rate at Town Creek. Like the maximum import rate at Town Creek, the maximum import rate at North Jones Creek occurred during the 4 th tidal cycle of the fall, spring tide. The greatest export rate through North Jones Creek was $34 \mathrm{~g} \mathrm{POC} \mathrm{s}^{-1}$ (Cycle 2, neap tide, May; Cycle 3, neap tide, July) which corresponded to $1.5 \mathrm{~kg}$ POC per tidal cycle. Unlike Town Creek, POC was exported from North Jones Creek on 6 of the 24 tidal cycles $(27 \%)$. The export periods were during the warmer months of May and July; whereas, imports were during the colder seasons. POC was imported during each of the 12 tidal cycles monitored in the winter and fall.

The highest import and export rates through South Jones Creek were $9 \mathrm{~g}$ POC $\mathrm{s}^{-1}$ (Cycle 2, neap tide, October) and approximately $50 \mathrm{~g} \mathrm{POC} \mathrm{s}^{-1}$ (Cycle 4 , spring tide, July; Cycle 1, sprint tide, November) respectively. POC was exported from South Jones Creek on 28 of the 32 tidal cycles ( $88 \%$ ).

Occasional diurnal discontinuities were observed in POC transport. A pattern of alternating low import or export during a tidal cycle followed by high transport was noted at Town and North Jones Creeks (Table 2). Examples are the May spring tide at Town Creek and the November spring tide at North Jones Creek. This
Net POC fluxes for each tidal cycle at each transect are presented in Table 2. Maximum transport rates 
Table 2. Net transports of POC for each tidal cycle studied at each transect

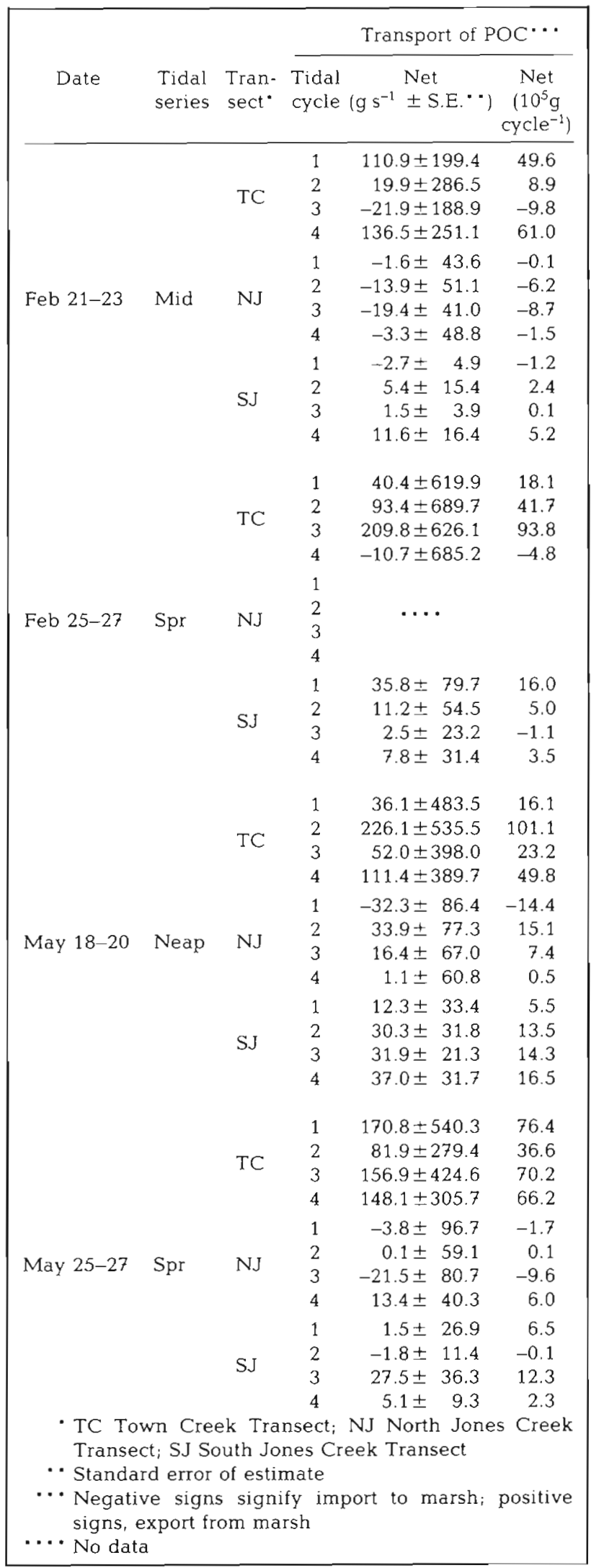

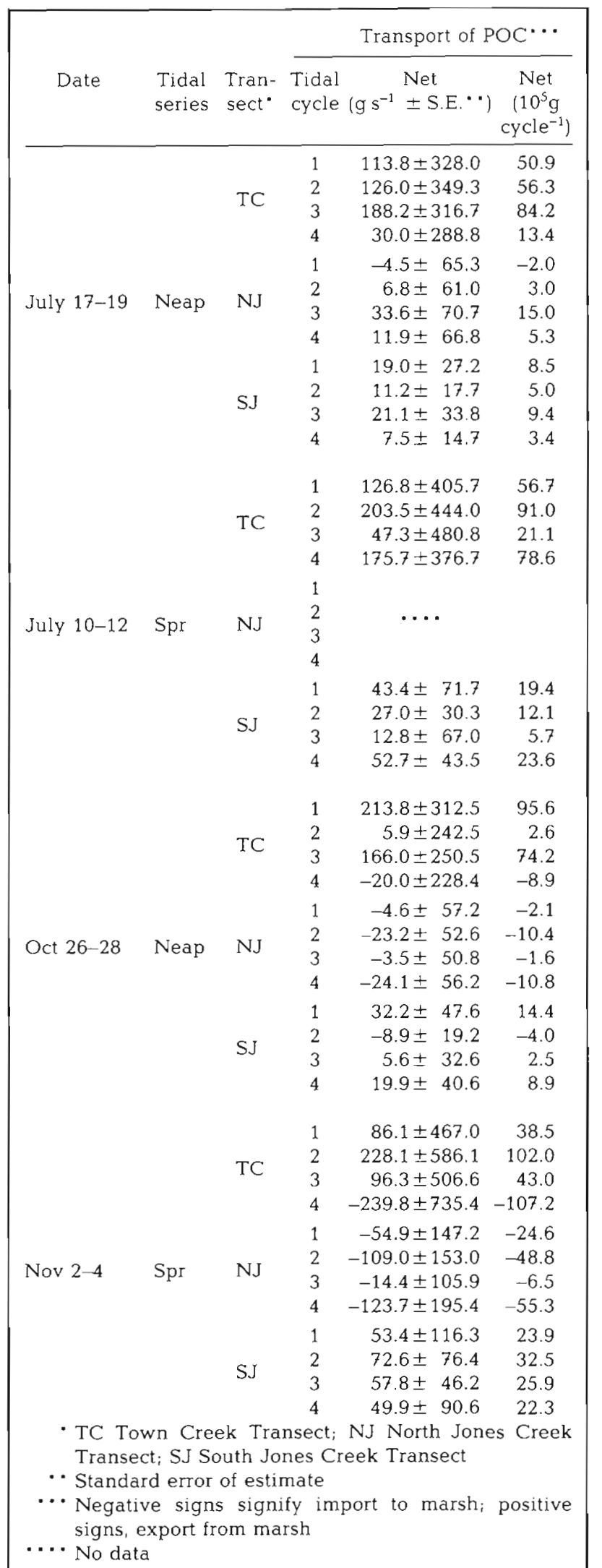


Table 3. Descriptive statistics for transport data collected during each sampling period

\begin{tabular}{|c|c|c|c|c|c|c|c|}
\hline \multirow[b]{3}{*}{ Date } & \multirow[b]{3}{*}{ Tidal series } & \multirow[b]{3}{*}{ Transect" } & \multirow[b]{3}{*}{$r^{2}$} & \multirow[b]{3}{*}{$P>/ t /$} & \multicolumn{3}{|c|}{ Transport of $\mathrm{POC} \cdot$} \\
\hline & & & & & \multicolumn{2}{|c|}{ Mean net } & \multirow{2}{*}{$\begin{array}{c}\text { Seasonal } \\
\text { average } \\
10^{5} \mathrm{gPOC} \\
\text { cycle }^{-1}\end{array}$} \\
\hline & & & & & $\begin{array}{c}10^{5} \mathrm{gPOC}^{-1} \cdots \\
\quad \pm \text { S.E. }\end{array}$ & $\begin{array}{c}10^{5} \mathrm{~g} \mathrm{POC} \\
\text { cycle }^{-1}\end{array}$ & \\
\hline \multicolumn{8}{|l|}{ Feb } \\
\hline $21-23$ & Mid & \multirow{2}{*}{$\mathrm{TC}$} & 0.89 & 0.091 & $71.5 \pm 40.1$ & 320 & \multirow{2}{*}{34.2} \\
\hline $25-27$ & Spr & & 0.97 & 0.200 & $81.4 \pm 62.0$ & 36.4 & \\
\hline $21-23$ & Mid & \multirow{2}{*}{ NJ } & 0.90 & 0.350 & $-7.4 \pm 7.7$ & -3.3 & \multirow{2}{*}{-3.3} \\
\hline $25-27$ & Spr & & & & & & \\
\hline $21-23$ & Mid & \multirow{2}{*}{ SJ } & 0.59 & 0.455 & $3.1 \pm 4.1$ & 1.4 & \multirow{2}{*}{4.3} \\
\hline $25-27$ & Spr & & 0.71 & 0.246 & $15.8 \pm 13.3$ & 7.1 & \\
\hline \multicolumn{8}{|l|}{ May } \\
\hline $18-20$ & Neap & \multirow{2}{*}{ TC } & 0.94 & 0.082 & $109.2 \pm 60.3$ & 48.8 & \multirow{2}{*}{49.4} \\
\hline $25-27$ & Spr & & 0.92 & 0.069 & $111.9 \pm 58.9$ & 50.0 & \\
\hline $18-20$ & Neap & \multirow{2}{*}{ NJ } & 0.93 & 0.689 & $4.3 \pm 10.5$ & 1.9 & \multirow{2}{*}{-0.7} \\
\hline $25-27$ & Spr & & 0.91 & 0.542 & $-7.1 \pm 11.5$ & -3.2 & \\
\hline $18-20$ & Neap & \multirow{2}{*}{ SJ } & 0.83 & 0.001 & $27.1 \pm 6.5$ & 12.1 & \multirow{2}{*}{7.1} \\
\hline $25-27$ & $\mathrm{Spr}$ & & 0.49 & 0.618 & $4.6 \pm 9.2$ & 2.1 & \\
\hline \multicolumn{8}{|l|}{ July } \\
\hline $17-19$ & Neap & \multirow{2}{*}{$\mathrm{TC}$} & 0.96 & 0.010 & $99.9 \pm 35.7$ & 44.7 & \multirow{2}{*}{52.6} \\
\hline $10-12$ & Spr & & 0.93 & 0.034 & $135.1 \pm 60.1$ & 60.4 & \\
\hline $17-19$ & Neap & \multirow{2}{*}{ NJ } & 0.92 & 0.349 & $9.3 \pm 9.8$ & 4.2 & \multirow{2}{*}{4.2} \\
\hline $10-12$ & Spr & & & & $\cdots$ & & \\
\hline $17-19$ & Neap & \multirow{2}{*}{ SJ } & 0.77 & 0.036 & $13.8 \pm 6.2$ & 6.2 & 103 \\
\hline $10-12$ & Spr & & 0.84 & 0.014 & $32.0 \pm 12.1$ & 14.3 & \\
\hline Oct/Nov & & & & & & & \\
\hline $26-28$ & Neap & TC & 0.95 & 0.008 & $92.3 \pm 31.8$ & 41.3 & 231 \\
\hline $2-4$ & Spr & TC & 0.96 & 0.867 & $10.7 \pm 62.9$ & 4.8 & 23.1 \\
\hline $26-28$ & Neap & NJ & 0.96 & 0.035 & $-12.9 \pm 5.8$ & -5.8 & -21.4 \\
\hline $2-4$ & Spr & Nu & 0.95 & 0.001 & $-82.7 \pm 17.5$ & -37.0 & -21.4 \\
\hline $26-28$ & Neap & SJ & 0.71 & 0.252 & $12.5 \pm 10.7$ & 5.6 & 15.3 \\
\hline $2-4$ & Spr & SJ & 0.76 & 0.019 & $55.7 \pm 22.2$ & 24.9 & 13.3 \\
\hline - TC Tow & k Transect; & Jorth Jone & ek $\operatorname{Tr}$ & SJ Sout & es Creek Transect & & \\
\hline - Negati & ns indicate im & to marsh; & ive si & port fror & & & \\
\hline$\because$ Standar & or of estimate & & & & & & \\
\hline$\cdots$ No data & & & & & & & \\
\hline
\end{tabular}

diurnal inequality was not observed at South Jones Creek (Table 2).

Net transports for each tidal series were calculated using Eq. 2 and are presented in Table 3. For Town Creek data, the descriptive equation accurately reproduced the observed transport patterns and comparison of descriptive and measured transports generated correlation coefficients $\left(r^{2}\right)$ that ranged from 0.89 to 0.97 . At North Jones Creek correlation coefficients ranged from 0.90 to 0.96 . POC transports through South Jones Creek were not as rhythmic as those through the northern interfaces; as a result, correlation coefficients ranged from 0.49 to 0.84 . Town Creek exported POC during each of the 8 tidal series monitored. The highest export rate, $135 \mathrm{~g} \mathrm{POC} \mathrm{s}^{-1}$, was calculated for the July, spring tide series, while the lowest rate was during the October/November spring tide series. Transports for each neap and spring tide were averaged to obtain seasonal rates. The highest seasonal rates of export were in spring and summer and the lowest rates in winter and fall. North Jones Creek imported POC during 4 of the 6 tidal series. The maximum import rate; $83 \mathrm{~g} \mathrm{POC} \mathrm{s}^{-1}$, occurred during the fall, spring tide series. The exports through this location were small with the largest only $9 \mathrm{~g}$ POC $5^{-1}$. The maximum seasonal rate occurred during the fall and was flooddirected. POC was exported through South Jones Creek during each tidal series. The rates were small, ranging between 3 and $56 \mathrm{~g} \mathrm{POC} \mathrm{s}^{-1}$. The maximum transport rate was during the fall, spring tide and the 
minimum rate was during the winter, mid tide. The maximum seasonal export rate through South Jones Creek was less than half the minimum rate at Town Creek.

Differences in transport rates may be partially explained by differences in volumes of water flowing past each transect. Estimates of the yearly average volumes flowing through the creeks are approximately $1.7 \times 10^{7}, 3.3 \times 10^{6}$, and $6.9 \times 10^{5} \mathrm{~m}^{3}$ per tidal cycle for Town, North Jones, and South Jones Creeks respectively (calculated according to Kjerfve et al., 1981).

POC was exported via Town Creek during each tidal series; however, only 3 of the 8 transport estimates (July, neap and spring tide; October/November, neap tide) were distinguished from zero transport at an acceptance level of $\alpha=0.05$ (2-tailed ' $\mathrm{T}$ ' test). When the acceptance level was widened to $\alpha=0.10$, the estimates from 3 additional periods were significantly different from zero (May, neap and spring tide; February, mid tide). Only 2 of the 6 transport estimates obtained at North Jones Creek were distinguished from zero $(\alpha=0.10)$. Both instances occurred during the October/November sampling and the net transports were flood-directed. The 8 flux estimates for South Jones Creek were ebb-directed and 4 were different from zero (May, neap tide; July, neap and spring tide; October/November, spring tide). In summary, 12 of the 22 tidal series estimates of net transport ( $55 \%$ ) were distinguishable from zero transport at $\alpha=0.10$ and 9 of the 22 estimates $(41 \%)$ were different from zero transport at the more critical acceptance level of $\alpha=0.05$. Considering significant transports at $\alpha=0.05$, all but one occurred during the summer or fall.

\section{DISCUSSION}

This study employed a sampling design in which samples were collected periodically throughout 4 consecutive tidal cycles. This design was a departure from the single tidal cycle sampling designs utilized in most previous transport investigations. As a result, we were able to demonstrate that transport rates are variable even among consecutive tidal cycles. The variability appears to be related to the diurnal inequality associated with a semi-diurnal tidal regime. Alternate tidal cycles had an increased discharge and a concomittant increased POC transport (compare for example Figs. $4 \mathrm{~A}$ and $\mathrm{B}$, bottom panel and the corresponding transport data from Table 2). Additionally, the transport direction was occasionally reversed on alternate tidal cycles (Fig. 4B, bottom panel and Table2). Erroneous conclusions may result concerning magnitude and direction of transport if data originating from single tidal cycle sampling designs are extrapolated to estimate monthly transport rates.

The fluctuation patterns of POC and tidal height offer insights into the ecological processes within the North Inlet Marsh. The majority of the POC was small suspended detritial material that could not move independently of the water mass. During the winter at Town and North Jones Creeks, POC concentrations fluctuated in phase with the tide, with higher concentrations of POC on rising than on falling tides. This pattern suggests the POC was coming in from the ocean and therefore imported to the marsh. During this period there was a net import of POC to North Jones Creek as the fluctuation patterns would predict, but not to Town Creek. The disparity resulted from a net export of water from Town Creek. When the mass balance of water was forced to zero and mass flux recalculated, the Town Creek system imported POC. The average export of water from Town Creek for any tidal series typically did not exceed $17 \%$ of the average tidal prism and normally freshwater input was less than $1 \%$ of the average tidal prism. (However, following a heavy winter snowfall and rapid melt, the export of water from Town Creek was close to $50 \%$ of the tidal prism.) The export of water above normal runoff may reflect a sampling bias due to estuarine discharge/refill events as a result of continental shelf waves which were not monitored randomly. Experiments are now being conducted to examine this possibility (B. Kjerfve, University of South Carolina, pers. comm.).

The in-phase fluctuation pattern of POC at the northern creeks for the winter was probably the result of POC from oceanic sources and suggest a period of depressed biological activity in the marsh relative to the ocean. This hypothesis is supported by data on 2 biological variables, chlorophyll $a$ and total microbial biomass, which mimicked the fluctuation patterns of POC (R. Zingmark, University of South Carolina, pers. Comm.; Chrzanowski and Stevenson, unpubl.). During spring, the POC fluctuations were a combination of inphase and out-of-phase patterns. Chrzanowski and Stevenson $(1979,1980)$, using filamentous fungi as an indicator of marsh sediment suggested fluctuations out-of-phase with the tide are indicative of resuspension of materials from the marsh surface. The shift in patterns during spring suggest a change from an inactive (dormant?) marsh to an active marsh. By summer the in-phase fluctuations were completely replaced by out-of-phase patterns, indicating an active marsh in terms of the formation and suspension of POC. In the fall, the decline of activity within the marsh was evidenced by a return of the combination of in-phase and out-of-phase fluctuations.

Similar shifts in patterns were marginally apparent 
at South Jones Creek; however, lack of rhythmical patterns limits data interpretation. Correlation coefficients between the described transport rates and actual values were not as high as those calculated for the northern locations. The low correlation coefficients and partial filtering of the tidal harmonic suggest that the shallow brackish water location was more strongly influenced by factors other than tidal changes.

Fifty-five percent $(\alpha=0.10)$ of the transport estimates were distinguishable from zero transport and the majority were during the summer and fall. Apparently significant POC transports between the North Inlet and ocean are a seasonal event with primary exports taking place in the summer and fall. These significant exports of POC seem to coincide with at least 2 other events: a rhythmic rise in sea level, and a period of increased biological activity within the marsh. Kjerfve (1978) has calculated that the surface of the North Inlet is inundated approximately $30 \%$ of the year. However, the extent of submergence varies over the year with $42 \%$ of the marsh inundated in fall (October) and only $27 \%$ covered in winter (January). When this hydrologic information is coupled with the increased biological activity of such burrowing organisms as Uca during summer, and senescence and seed production of Spartina during fall, it seems to offer at least one possible mechanism to account for the POC exports during these seasons.

A major consideration in computing an annual budget involves extrapolating the data to an entire season. The experimental design has provided a very good estimate of net POC movement between marsh and ocean for 8 tidal cycles each season. We assume these net fluxes are representative of the entire season. However, annual budgets based on this assumption may be subject to some of the same problems associated with extrapolating single tidal cycle samplings (see beginning of discussion) and a certain amount of care must be taken in interpretation.

The breakdown of the year into seasons was based on monthly water temperatures for the 2 previous years and the seasonal production and mortality of Spartina for a Georgia marsh (Gallagher et al., 1980). Months with similar features were grouped together. The mean net transport for February was considered representative of transports during the winter months of January, February, and March 1-16. The data collected during May were considered representative of the spring months of March 17-31, April, and May. July's results were taken as typical of June, July, August, and September, and the data for October/November were considered typical of October, November, and December.

Annual transport budgets may be calculated in 2 ways: the first method considers all data regardless of statistical significance; whereas, the second method considers transport estimates determined to be statistically different from zero. When all data were used, POC was exported from Town Creek at an annual rate of $2.8 \pm 0.6 \times 10^{9} \mathrm{~g} \mathrm{yr}^{-1}$, imported to North Jones Creek at an annual rate of $3.6 \pm 1.1 \times 10^{8} \mathrm{~g} \mathrm{YI}^{-1}$, and exported from South Jones Creek at $6.7 \pm 1.3 \times 10^{8} \mathrm{~g}$ $\mathrm{yr}^{-1}$. These transports corresponded to average annual rates of $89 \mathrm{~g} \mathrm{POC} \mathrm{s}^{-1}$ at Town Creek, $11 \mathrm{~g} \mathrm{POC} \mathrm{s}^{-1}$ at North Jones Creek, and $21 \mathrm{~g} \mathrm{POC} \mathrm{s}^{-1}$ at South Jones Creek.

Annual net transports based on statistically significant data were calculated by replacing nonsignificant transport estimates with zero and recalculating. Considering only significant data, POC was exported from Town Creek at an annual rate of $2.6 \pm 0.5 \times 10^{9} \mathrm{~g}$ $\mathrm{yr}^{-1}$, imported to North Jones Creek at $3.8 \pm 0.8 \times 10^{8} \mathrm{~g} \mathrm{yr}^{-1}$, and exported from South Jones Creek at a rate of $5.5 \pm 0.8 \times 10^{8} \mathrm{~g} \mathrm{yr}^{-1}$. The similarity between transport estimates based on each method is probably a random result brought about by the fortuitous cancelling of import and export terms. The 2 methods are not comparable.

Town, North Jones, and South Jones Creeks account for most (approximately $95 \%$ ) of the water flow through the North Inlet ecosystem. This allows a basis for a reasonable assessment of ecosystem function in terms of POC transport. Based on significant data, the system contributed $2.8 \pm 0.5 \times 10^{9} \mathrm{~g} \mathrm{POC} \mathrm{yr}^{-1}$ to the non-marsh environment. The intertidal marsh surface is $2513 \mathrm{ha}$; assuming the marsh evenly contributes to the net flux, the annual transport corresponded to $111 \pm 20 \mathrm{~g}$ of $\mathrm{POC} \mathrm{m}^{-2} \mathrm{yr}^{-1}$. If creeks are included into area estimates, the surface area increases to 3222 ha and the annual net export would correspond to $87 \pm 16 \mathrm{~g} \mathrm{POC} \mathrm{m}^{-2} \mathrm{yr}^{-1}$.

The relative importance of each creek in terms of water and POC movements was estimated by considering the tidal prisms of each (Kjerfve et al., 1981). Town Creek accounted for approximately $81 \%$ of the total water flow through the 3 creeks, North Jones accounted for approximately $16 \%$, and South Jones only $3 \%$. As may be expected, movements of POC closely followed water movements. Approximately $80 \%$ of the total POC movement was through Town Creek, $15 \%$ through North Jones Creek, and $5 \%$ through South Creek. In terms of the total non-directional movement of POC and water, the largest creek monitored, Town Creek, seemed to be the most important of the 3 creeks.

The relative importance of each creek in terms of total POC movement and directional net flux of POC was estimated by considering a ratio of the percentage of the net POC flux (only statistically significant data) to the percentage of the POC movement (non-directional) for each creek. The relative contribution by 
each creek to the total significant net POC flux was $73 \%, 11 \%$, and $16 \%$ for Town, North Jones, and South Jones Creeks respectively. The ratios of the percentage of the net POC flux to the percentage of the total POC movement through each creek were 0.9 for Town Creek, 0.7 for North Jones Creek, and 3.2 for South Jones Creek. The ratio obtained for South Jones Creek (the brackish water interface) was at least 3 times greater than the ratios for either of the 2 ocean interfaces. It appears that South Jones Creek, while having a relatively minor role in the total water $(3 \%)$ and total POC (5\%) movements, assumes a more important role in the actual net export of POC from the North Inlet marsh system than its size indicates.

The net primary production of Spartina within the North Inlet ecosystem has yet to be reliably estimated, but considering production estimates for North Carolina marshes (Stroud and Cooper, 1965, Williams and Murdock, 1966, 1969) and Georgia marshes (Gallagher et al, 1980), aerial net production probably falls between 1200 and $2000 \mathrm{~g}$ of dry biomass $\mathrm{m}^{-2} \mathrm{yr}^{-1}$. Assuming $45 \%$ of the biomass is carbon, the net export of POC from the North Inlet ecosystem was approximately 10 to $16 \%$ of the production of the grass. The export (or import) of POC from the North Inlet system varies according to the drainage area of each creek. It is difficult to assess the area of marsh drained by North and South Jones Creeks due to complex circulation patterns and the dendritic anastomosing nature of creeks within the surrounding marsh; however, the drainage area of Town Creek was estimated to be 1800 ha (Chrzanowski and Stevenson, 1979). Integrating the annual POC export over the estimated drainage area yields an annual export corresponding to 14 to $24 \%$ of the above ground production of Spartina. This estimate agrees with Nixon and Oviatt's (1973) report of an export of 10 to $30 \%$ of the annual production of a Rhode Island marsh.

When the North Inlet system is considered as a whole, the reported export of 9 to $16 \%$ of the estimated annual production was considerably less than the export percentages reported for several other marsh systems. Teal (1962), working from a community energy budget, reported a loss of $43 \%$ of the above ground production of Georgia marsh. A greater than $40 \%$ loss of production of a Louisiana salt marsh and shallow bay system was reported by Day et al. (1973). In a more recent study, Valiela et al. (1978) indicated POC export from the Great Sippeswisett Marsh to Buzzards Bay was equivalent to $40 \%$ of the net annual above ground productivity of Spartina. Heinle and Flemer (1976), following a 2-year study of Gott's Marsh, demonstrated a net export of both water and carbon. However, if their data are reworked so transport calculations are based solely on the year for which a working current meter was available, the direction of net water and carbon transport was reversed from an export to an import. An additional study of marsh transport processes that indicated an import of POC to a marsh is that of Woodwell et al. (1977), who reported that Flax Pond collects POC at a rate of $60 \mathrm{~g} \mathrm{C} \mathrm{m}^{-2}$ $\mathrm{yr}^{-1}$. Nixon (1980) has prepared a through review of studies dealing with directional flows of materials through salt marsh systems and predicted that marshes should export between 100 to $200 \mathrm{~g}$ of organic carbon $\mathrm{m}^{-2} \mathrm{yr}^{-1}$

Acknowledgements. These data were collected with the help of an interdisciplinary research group supported by National Science Foundation grant DEB 7683010. Hydrographic data were supplied by Bjom Kjerfve. Special thanks to Steven Knoche, Chuck Wilson, Mike Taillon, and Jim Clark for their capable technical assistance.

\section{LITERATURE CITED}

Axelrad, D. M., Moore, K. A., Bender, M. E. (1976). Nitrogen phosphorus, and carbon flux in Chesapeake Bay marshes Virginia, Virginia Water Resources Center

Chrzanowski, T H., Stevenson, L. H. (1979). Material fluxes through the North Inlet marsh system: short-term fluctuations of fungi and related parameters. Mycologia 71 958-967

Chrzanowski, T. H., Stevenson, L. H. (1980). Filamentous fungi as indicators of sediment-detritus resuspension. Botanica Mar. 23: 251-256

Chrzanowski, T. H., Stevenson, L. H., Kjerfve, B. (1979). Adenosine 5 -triphosphate flux through the North Inlet marsh system. Appl. environ. Microbiol. 37: 841-848

Chrzanowski, T. H., Stevenson, L. H., Kjerfve, B. (1981). Microbial biomass variability in salt-marsh creek crosssections. Mar Geology 40: 155-170

Day, J. W., Jr., Smith, W. G., Wagnet, P. R. (1973) . Community structure and carbon budget of a salt marsh and shallow bay estuarine system in Louisiana, Louisiana State University, Center Wetland Resources

Gallagher, J. L., Reimold, R. J., Linthurst, R. A., Pfeiffer, W. J. (1980). Aerial production, mortality, and mineral accumulation-export dynamics in Spartina alterniflora and Juncus romerianus plant stands in a Georgia salt-marsh. Ecology 61: $303-312$

Happ, G., Gosselink, J. G., Day, J. W., Jr. (1977). The seasonal distribution of organic carbon in a Louisiana estuary. Estuar. coast. mar. Sci. 5: 695-705

Heinle, D. R., Flemer, D. A. (1976). Flows of materials between poorly flooded tidal marshes and an estuary. Mar. Biol. 35: 359-373

Helwig, J. T., Council, K. A. (1979). SAS users guide, SAS Institute Incorporated, Raleigh

Kjerfve, B. (1975). Velocity averaging in estuaries characterized by a large tidal range to depth ratio. Estuar. coast. mar. Sci. 3: 311-323

Kjerfve, B., Greer, J. E., Crout, R. L. (1978). Low frequency response of estuarine sea level to non-local forcing. In: Wiley, M. (ed.) Estuarine interactions. Academic Press, New York, pp. 497-513

Kjerfve, B., Stevenson, L. H., Proehl, J. A., Chrzanowski, T H. (1981). Estimation of material fluxes in an estuarine cross- 
section: a critical analysis of spatial measurement density and errors. Limnol. Oceanogr. 26: 325-335

Nixon, S. W., Oviatt, C. A (1973). Ecology of a New England salt marsh. Ecol. Monogr. 43; 463-498

Nixon, S. W. (1981). Between coastal marshes and coastal waters - a review of twenty years of speculation and research on the role of salt marshes in estuarine productivity and water chemistry. In: Hamilton, R., MacDonald, K. B. (eds.) Estuarine and wetland processes with emphasis on modeling. Plenum Publishing Corporation, New York, pp. $437-527$

Odum, E. P., De la Cruz, A. A. (1967). Particulate organic detritus in a Georgia salt-marsh estuarine ecosystem. In: Lauff, G. H. (ed.) Estuaries. Publs Am. Ass. Advmt Sci., pp $383-388$

Pritchard, D. W., Burt, W. V. (1951). An inexpensive and rapid technique for obtaining current profiles in estuarine waters. J. mar. Res. 108: 180-189

Settlemyre, J. L., Gardner, R. L. (1975). Chemical and sediment budgets for a small tidal creek, Charlestown Harbor S.C. Clemson University, Clemson, Water Resources Research Institute Report Number 57

Settlemyre, J. L., Gardner, R. O. (1977). Suspended sediment flux through a salt marsh drainage basin. Estuar. coast. mar. Sci. 5: 653-663
Strickland, T. D. H., Parsons, T. R. (1968). A practical handbook of seawater analysis. Fish. Res. Bd Can., Bull. 167. $1-311$

Stroud, L. M., Cooper, A. W (1968). Color-influenced aerial photographic interpretation and net primary productivity of a regularly flooded North Carolina salt marsh. North Carolina Water Resources Research Institute, Raleigh, Report 12

Teal, J. M. (1962). Energy flow in the salt marsh ecosystem of Georgia. Ecology 43: 614-624

Valiela, I., Teal, J. M., Volkmann, S., Shafer, D., Carpenter, E. J. (1978). Nutrient and particulate fluxes in a salt marsh ecosystem: Tidal exchanges and inputs by precipitation and groundwater. Limnol. Oceanogr. 23: 798-812

Williams, R. B., Murdock, M. B. (1966). Annual production of Spartina alterniflora and Juncus roemerianus in salt marshes near Beaufort, North Carolina. Assoc. Southeastern Biologist Bull. 13: 49

Williams, R. B., Murdock, M. B. (1969). Compartmental analysis of production and decay of Juncus roemerianus. Assoc Southeastern Biologists Bull. 15: 59

Woodwell, G. M., Whitney, D. E., Hall, C. A. S., Houghton, R. A. (1977). The Flax Pond ecosystem study: exchanges of carbon in water between a salt marsh and Long Island Sound. Limnol. Oceanogr. 22: 823-828

This paper was submitted to the editor; it was accepted for printing on November 18,1981 